\title{
Banking sector strength and the transmission of currency crises
}

Citation for published version (APA):

Bruinshoofd, W. A., Candelon, B., \& Raabe, K. (2005). Banking sector strength and the transmission of currency crises. METEOR, Maastricht University School of Business and Economics. METEOR Research Memorandum No. 022 https://doi.org/10.26481/umamet.2005022

Document status and date:

Published: 01/01/2005

DOI:

10.26481/umamet.2005022

Document Version:

Publisher's PDF, also known as Version of record

\section{Please check the document version of this publication:}

- A submitted manuscript is the version of the article upon submission and before peer-review. There can be important differences between the submitted version and the official published version of record.

People interested in the research are advised to contact the author for the final version of the publication, or visit the DOI to the publisher's website.

- The final author version and the galley proof are versions of the publication after peer review.

- The final published version features the final layout of the paper including the volume, issue and page numbers.

Link to publication

\footnotetext{
General rights rights.

- You may freely distribute the URL identifying the publication in the public portal. please follow below link for the End User Agreement:

www.umlib.nl/taverne-license

Take down policy

If you believe that this document breaches copyright please contact us at:

repository@maastrichtuniversity.nl

providing details and we will investigate your claim.
}

Copyright and moral rights for the publications made accessible in the public portal are retained by the authors and/or other copyright owners and it is a condition of accessing publications that users recognise and abide by the legal requirements associated with these

- Users may download and print one copy of any publication from the public portal for the purpose of private study or research.

- You may not further distribute the material or use it for any profit-making activity or commercial gain

If the publication is distributed under the terms of Article $25 \mathrm{fa}$ of the Dutch Copyright Act, indicated by the "Taverne" license above, 


\title{
Banking Sector Strength and the Transmission of Currency Crises
}

\author{
Allard Bruinshoofd ${ }^{1}$, Bertrand Candelon ${ }^{2,3}$ and Katharina Raabe ${ }^{2}$
}

5 April 2005

\begin{abstract}
We show that, complementary to trade and financial linkages, the strength of the banking sector helps explain the transmission of currency crises. Specifically, we demonstrate that the Mexican, Thai, and Russian crises predominantly spread to countries with weaknesses in their banking sectors. At the same time, the role of banking sector strength varies per crisis; where the Mexican crisis spread to countries with a strong presence of foreign banks in domestic credit provision, the Thai crisis disproportionately contaminated countries where the banking sector was most sensitive to currency realignments, while the Russian crisis spread to countries with inefficiencies in the banking sector.
\end{abstract}

JEL Classification: F30; F32; F34

Keywords: Banking Sector Strength, Currency Crisis, Transmission Channels.

${ }^{1}$ De Nederlandsche Bank - Research Division

2 Maastricht University - Department of Economics

${ }^{3}$ Corresponding author. Phone: +31-43-388-3442; fax: +31-43-388-4864. Mail: Maastricht University - Department of Economics, P.O. Box 616, 6200 MD Maastricht, the Netherlands.

E-mail: $\underline{\text { b.candelon@algec.unimaas.nl }}$

* We thank Peter van Els, Ralph de Haas, Jan Kakes and Cees Ullersma for useful comments. All remaining errors are our own. The views expressed in this paper are those of the authors and do not necessarily reflect those of De Nederlandsche Bank. 


\section{I ntroduction}

Recent currency turbulences in, for example, Latin America and Asia have paved the way for a growing literature around the concept of contagion (e.g. Glick and Rose, 1999; Van Rijckeghem and Weder, 2001; Forbes and Rigobon, 2002). The aim of this literature is to increase our understanding of the diffusion of a shock affecting any particular "ground-zero" country to other countries. This entails, on the one hand, the identification of the relevant factors involved and, on the other hand, an assessment of the stability of their relative weights in the diffusion process. ${ }^{1}$

The literature has so far identified trade and financial linkages as the two most important channels of crisis transmission, while fundamental macroeconomic variables play only a minor role (e.g. Glick and Rose, 1999; Van Rijckeghem and Weder, 2001). The role of trade linkages builds on the argument of competitive devaluation. If a specific country $A$ realigns its exchange rate, then a particular country $B$ suffers a loss in competitiveness in third markets where it competes with products from country A. Hence the shock that forced country $A$ to realign its exchange rate may transmit to country $B$ through trade competition in third markets. Glick and Rose (1999) find empirical support for the trade competition channel using data on five different currency crises. ${ }^{2}$ The role of financial linkages derives from the common bank lender effect, which builds on risk management techniques used by banks (e.g. Kaminsky and Reinhart, 2000; Van Rijckeghem and Weder, 2001). The common bank lender effect states that banks - when their exposures in a particular country are hit by a currency crisis - reduce investments in related markets, causing a credit crunch there. Van Rijckeghem and Weder (2001) find a clear common lender effect in the propagation of the Mexican, Asian, and Russian crises.

As the main creditors tend to concentrate their loans in specific regions in the world, and trade linkages tend to be predominantly regional as well, both trade and financial linkages speak to the regional transmission of currency crises. An interesting identification problem naturally results; though separately trade and financial linkages perform well in explaining patterns of crisis transmission, taken together they substitute rather than complement each other. Furthermore, their explanatory power remains moderate at best, suggesting that other channels may also exist.

\footnotetext{
${ }^{1}$ One stream of the contagion literature avoids the issue of identifying the transmission channels and looks for an increase in the market linkages. This approach is generally referred to as shift contagion (e.g. Forbes and Rigobon, 2002; Candelon et al., 2005).

${ }^{2}$ The crises are the breakdown of the Bretton Woods system in 1971, the collapse of the Smithsonian Agreement in 1973, the EMS crisis of 1992-93, the Mexican meltdown of 1994 and the Asian flu of 1997. These results corroborate findings by for example Eichengreen et al. (1996), Kaminsky and Reinhart (2000), Hardy and Pazarbasioglu (1998).
} 
Sbracia and Zaghini (2003) suggest that the specificities of banking activities generate several potential channels for the transmission of currency crises. In particular, maturity transformation may be at the origins of bank panics, illustrated by bank runs, leaving the banking system in search of liquidity. In a globally integrated banking sector, the liquidity crunch can be transmitted to other economies. Caramazza et al. (2000) and Herrero (1999), using different proxies $^{3}$ to represent asset maturity transformation, find a propagation effect for Venezuela. To mitigate these problems, international financial authorities have set up rules to help banks in distress. As a by-product, however, this may introduce moral hazard behavior that in itself may foster contagion. Although the moral hazard phenomenon is empirically rather hard to measure, Demirgüç-Kunt and Detragiache (1998) use deposit insurance as a proxy and find some support that moral hazard may explain crisis contagion.

Although several studies have begun to empirically analyze the role of the banking sector as a part entière channel of crisis transmission, a systematic analysis of the role of bank balance sheets (usually labeled banking sector quality or strength) as a factor of crisis transmission has yet to be performed. In this paper we take steps in that direction by paying closer attention to the financial channels that may help explain the transmission of crises. Specifically, we attempt to distinguish the role of banking sector strength from that of common lender effects as captured by financial linkages. As the nature of currency crises changes over time (Saxena, 2004), we find it conceivable that the nature of the transmission of crises changes over time. Accordingly, we analyze the transmission of the Mexican, Thai, and Russian crises separately. In line with previous studies, we find that the 1994 Mexican meltdown, as well as the 1997 Asian flu, was predominantly regionally transmitted via trade and financial linkages. The transmission of the 1998 Russian crisis, however, also ran via specific banking channels. This changing nature of crisis transmission may explain why the Russian crisis diffused relatively more across regions, whereas the Mexican and Thai crises remained largely regional.

The plan of the paper is as follows. The next section provides a comprehensive discussion of the role of the banking sector in financial crisis transmission. Section 3 outlines the empirical strategy and the results are presented and discussed in section 4 . Section 5 concludes.

\footnotetext{
${ }^{3}$ They both introduce the ratio of broad money to international reserves and short-term debt to international reserves in order to represent the ability of the financial system to withstand currency pressures.
} 


\section{I. The Role of Banking Sector Strength in Crisis Contagion}

This paper argues that banking sector strength positively affects the extent to which countries can absorb external shocks. The analysis is in the spirit of Sachs et al. (1996) who argue in favour of a negative relationship between the strength of a country's banking system and its vulnerability to contagion. In our view, a strong banking sector consists of banks that only grant loans on which the interest revenues cover all the risks that the banking sector is exposed to. That is, a strong banking system is comprised of banks that are able to correctly price the risks associated with the intermediation of funds such as asset transformation and maturity transformation. ${ }^{4} \mathrm{~A}$ strong banking system will thus limit the possibility of the transmission of a crisis by reducing transmission channels due to risk management and asset maturities transformation. This involves extensive monitoring and screening of debtors by banks and cumulates in the allocation of financial funds to their most efficient use. The ability of banks to correctly price risk is reflected in a low share of nonperforming loans and in high levels of profits, efficiency, capital, and liquidity. These factors, in turn, are positively related to the degree of confidence that markets have in the stability of the banking system. Confidence in the stability of the financial system is at the core of economic stability, vice versa.

Krugman (1999) argues that the banking system does not have to be weak at the onset of a financial crisis. The weaknesses may arise in the course of a crisis from the balance sheet problems of debtors and/or from loss of investors' confidence in the stability of the financial system. Notably, according to Krugman the bad loan problem is a consequence rather than the cause of a financial crisis. It has its origin in a transfer problem according to which a reversal in capital inflows necessitates a reversal in the current account balance from a deficit to a surplus. This reversal can be accomplished through a deliberately advocated recession or through an exchange rate devaluation. Indisputably, a fall in absorption and the corresponding economic downturn worsens the balance sheet position of debtors and weakens the banking system through its positive effect on the debt default rate. Banks are assumed to respond to the increase in the debt default rate by reducing the supply of loans. In restricting the private sector's access to external funds, banks cause a credit crunch with detrimental effects on the performance of the economy.

Krugman (1999) reasons that the problem of non-performing loans does not weaken the banking system per se if banks are re-capitalized. The bad loan problem only destabilizes

\footnotetext{
${ }^{4}$ Lindgren et al. (1996) stress low levels of profitability, cash and capitalization, high debt and a high responsiveness to changes in domestic and foreign interest rates as characterizing factors of a weak banking system.
} 
the banking system if investors loose confidence regarding the stability of the banking system. The loss in confidence may arise from a currency devaluation, which is advocated to match the reversal of capital inflows. Similar to a fall in absorption, the real depreciation of the domestic currency worsens the balance sheet position of firms and households by raising the real costs of holding loans denominated in foreign currency. This development, in turn, contributes to the weakness of the banking system by raising the loan default rate.

Similar to Krugman (1999), Sachs et al. (1996) and Tornell (1999) stress a decline in absorption and currency devaluation as policies that can be engineered to cope with contagious effects of shocks originating in the ground zero country (hereafter simply, ground zero). More specifically, Sachs et al. (1996) emphasize that the choice of the appropriate policy crucially depends on the strength of the banking system at the start of a crisis period. ${ }^{5}$ If the banking system is characterized by a high share of non-performing loans at the start of a cris is, an engineered recession amplifies the weakness of the banking system through its positive effect on the debt default rate. In anticipation of such an effect, Sachs et al. (1996) argue that a government will advocate currency devaluation rather than a fall in absorption to deal with contagious effects in the presence of a weak banking system.

Sachs et al. (1996) and Tornell (1999) view bad loans as the outcome of periods of bank lending booms. These periods are associated with financial market liberalization; a development which comes along with poor mechanisms of prudential supervision and regulation. ${ }^{6}$ The process of financial market liberalization has two interrelated implications. Firstly, it increases the willingness and ability of banks to grant loans. Secondly, it improves the terms under which debtors can obtain funds from banks. These aspects, in addition to the lagging development of expertise, credit market imperfections, and institutional and policy deficiencies related to bank supervision and regulation imply that banks may not correctly price risk and may invest in risky and poorly performing projects. The credit expansion correspondingly increases the average share of bad loans and deteriorates the quality of the banks' loan portfolios. This, in turn, increases the sensitivity of the - possibly undercapitalized - banking systems to reversals in capital inflows.

The inability of banks to correctly price risk is reflected not only in the share of nonperforming loans, but also in the overall cost efficiency, profitability, and liquidity of the banking sector. These variables co-define the exposure of banks to shocks and determine their ability to absorb contagious effects and to accommodate bank runs. The level of bank liquidity at the onset of a foreign crisis matters as it may affect the confidence of depositors

\footnotetext{
${ }^{5}$ The models implicitly exclude the possibility that banks are re-capitalized.

${ }^{6}$ Corsetti et al. (1998) provides descriptive evidence of the role of excessive lending in a deregulated banking system as cause of the Asian crisis.
} 
regarding the ability of banks to meet large withdrawals. Depositor confidence is a necessary - though not a sufficient - condition to avoid a run on deposits. In order to meet liquidity requirements in the face of large deposit withdrawals, the banks' natural response is to curb lending. The contraction in loan supply has two interdependent effects. Firstly, the credit contraction comes at the expense of real economic activity through its negative effect on investment and consumption spending. Secondly, the credit crunch and the corresponding decline in economic activity worsen the balance sheet position of firms and households and raises the share of non-performing loans. These developments cause the quality of the overall loan portfolio to deteriorate and intensify the motive to run on deposits. The underlying effects are, therefore, self-reinforcing and cumulate in an unsound or insolvent banking system.

DeYoung and Whalen (1994) argue that the share of non-performing loans decreases with the cost efficiency of banks. At the core of this relationship is the notion that efficient banks operate more stringent monitoring standards than inefficient banks. Assuming a direct positive link between the cost efficiency and profitability of banks, a virtuous circle may ensure that efficient banks can impose higher monitoring standards (i.e. can direct expenses foregone elsewhere to the screening and monitoring debtors). This reduces credit risk per se and helps to secure a stable stream of interest income. Furthermore, it adds to the overall level of capital, which implies that cost-efficient banks are better protected against adverse developments than cost-inefficient banks. These relationships also explain why a banking system consisting of efficient banks is likely to absorb shocks and consequent economic downturns better than one composed of inefficient banks. The reason is that efficient banks face fewer pressures to contract their loan supply in the presence of adverse economic developments or deposit withdrawals because they are more likely to meet capital adequacy requirements than inefficient banks. Furthermore, Fries et al. (2002) argue that efficient banks abstain from taking excessive risk if the probability of failure and the consequent loss of capital are high. ${ }^{7}$

It follows from Peek and Rosengreen (2000) and De Haas and Van Lelyveld (2004) that the stability of the banking sector may also depend on the degree of foreign bank penetration. However, the nature of this relationship is not unambiguous. ${ }^{8}$ Foreign-owned banks can stabilize the performance of the domestic banking system if they are more efficient than domestic banks. Relative efficiency gains arise from cross-border diversification and the exploitation of associated cost-saving scope and/or scale economies. If effective,

\footnotetext{
${ }^{7}$ Fries et al. (2002) associate the loss of capital with the loss of the banking license.

${ }^{8}$ See De Haas and Van Lelyveld (2004) for a detailed survey of the positive and negative effects of foreign bank operation in domestic markets.
} 
these gains cause the domestic credit provision by foreign-owned banks to be less sensitive to the exogenously determined changes in interest rate margins than credit supply by domestically owned banks. In being more stable, credit supply by foreign owned banks may limit the magnitude and frequency of lending booms. Since this also reduces the rate of loan default, the operation of foreign-owned banks is expected to stabilize the performance of the domestic banking system. Closely related to this argument, the geographical scope of activity enables foreign-owned banks to operate a loan portfolio that is more diversified and less susceptible to shocks and contagious effects than that of domestic banks. Foreign-owned banks may for that reason be viewed as 'safe havens' in the domestic banking market, which limits capital outflows during a financial crisis. The presence of foreign-owned banks can also directly stimulate the stability of the domestic banking system by providing access to new management techniques and information technologies. Foreign bank management practices and information technologies improve the quality and efficiency of banking services and lower the costs of funds intermediation. With credits becoming cheaper, the efficiency gains mitigate the severity of the loan default problem, thereby stabilizing the banking system. These positive effects on banking sector stability are amplified if it holds that foreign bank penetration has a positive impact on banking practices, regulation, and supervision.

Under some circumstances, however, the presence of foreign-owned banks may also destabilize the domestic banking system. One argument in this regard stresses the effect of foreign bank penetration on the degree of short-run concentration of banks. The entry of foreign banks may reduce the degree of concentration of the banking sector. If domestic banks fail to adjust to the increased competitive pressures, the domestic banking sector is likely to be characterized by banking failures and, consequently, financial instability. Another argument is that foreign banks may also be least committed to a country, so that they may also be the first to cut their losses when the going gets tough. ${ }^{9}$

In the empirical analysis of the role of banking sector strength in the transmission of currency crises we consider various proxies of the features of banking sector strength discusses so far. Detailed definitions and data sources are in the appendix. We now turn to the empirical implementation of crisis transmission analysis.

\section{I . Empirical Strategy}

We are primarily interested in the transmission of currency crises across countries (cf. Glick and Rose, 1999; Van Rijckeghem and Weder, 2001). We therefore analyze why a crisis in

\footnotetext{
${ }^{9}$ De Haas and Van Lelyveld (2005) and Morgan et al. (2003) take a portfolio view of multinational banking to support such an argument.
} 
ground zero transmits to some countries, but not to others. The present analysis considers the Latin American, Asian, and Russian crises. Following common patterns, the crisis episodes are correspondingly modeled to originate with Mexico (December 20, 1994), Thailand (July 2, 1997) and Russia (August 18, 1998). We test for the existence of crisis contagion by estimating cross-section probit regressions. These measure the relative importance of banking variables as factors which affect the probability of observing a financial crisis in country i given a financial crisis in the ground zero country. To accommodate alternative channels of crisis contagion, we also control for trade and financial linkages as well as a score of miscellaneous macroeconomic controls. The probit model has the following form:

$$
\mathbb{N D}_{i}=\alpha \mathrm{TRD}_{\mathrm{i}}+\beta \mathrm{FIN}_{\mathrm{i}}+\delta \mathrm{MCR}_{\mathrm{i}}+\gamma \mathrm{BNK}_{\mathrm{i}}+\varepsilon_{\mathrm{i}}
$$

where $\varepsilon_{\mathrm{i}}$ represents normally distributed error terms and subscript $\mathrm{i}$ is a country index with $\mathrm{i}=1, \ldots, \mathrm{N}$ (number of countries). IND $\dot{\mathrm{s}}$ the binary crisis indicator that equals unity if country i suffered a financial crisis after a crisis hit the ground zero country and zero otherwise. ${ }^{10}$ We use the crisis classifications as defined by Glick and Rose (1999) and Van Rijckeghem and Weder (2001) who distinguish crisis from non-crisis countries by using journalistic and academic histories and the views of IMF economists (see the appendix). The motivation for this choice of crisis indicator is to enable a comparison between our results and these influential papers. TRD and FIN are the proxy variables for trade and financial linkages. We control for trade linkages by including the measures of trade competition in third markets as defined by Glick and Rose (1999) and applied by Van Rijckeghem and Weder (2001), among others. This measure of trade competition accounts for the degree to which any country competes with ground zero in foreign export markets. We control for financial linkages by considering the measure of funds competition as defined by Van Rijckeghem and Weder (2001). Funds competition measures the extent to which country $\mathrm{i}$ competes for bank loans from the same lenders as ground zero. Stronger competition for trade and finance with ground zero meanwhile also raises the sensitivity of a particular country to crisis contagion. MCR represents a set of macroeconomic control variables that are related to the external and internal balance of a country prior to the crisis in ground zero. ${ }^{11}$ These variables are included to account for disequilibria in macroeconomic

\footnotetext{
${ }^{10}$ On the right-hand side of the equation we include only information that predates the crisis to avoid endogeneity.

${ }^{11}$ Detailed descriptions of the trade, financial, and macroeconomic variables are in the appendix.
} 
fundamentals, which may leave a country vulnerable to a currency crisis as distinct from trade and financial linkages.

BNK denotes the set of variables related to banking sector strength. We follow Sachs et al. (1996) and Tornell (1999) and assume that the strength of the banking sector at the start of a crisis period determines the sensitivity of a country to shocks originating in the ground zero country. We select several measures of banking sector strength accordingly. These variables characterize the strength of the banking system by stressing the relative importance of non-performing loans and by emphasizing the risk exposure of banks as measured by liquidity, profitability and efficiency. Despite their theoretical motivation, the choice of variables is abo restricted by the availability and quality of data and by the comparability of data across countries. The selected variables should therefore be viewed as approximations of the underlying features of banking sector strength.

We use several variables to capture the strength of the banking sector as indicated by the degree of credit expansion. Rough measures of credit expansion are claims on the private sector and claims on the government and other public entities. These variables do not characterize the claim and do not distinguish the source of claim. More details are embedded in i.) domestic credit as provided by the banking sector (bank assets to GDP) and ii.) private credit as provided by deposit money banks (private credit by banks). Published by the Worldbank, these variables are expressed as a share of GDP. ${ }^{12}$ Besides these variables, the stability of the banking system is approximated as in Sachs et al. (1996) and Tornell (1999) with a lending boom index that reflects the speed of credit expansion. This index is computed as the real percentage change in loans that banks grant to the private sector and to state-owned enterprises over a four-year pre-crisis period. What all these measures of (excessive) bank credit expansion have in common is that for each country theoretically an increase in these measurements depicts a weakening in the banking sector, which may increase the probability that the crisis in ground zero spreads to this particular country. ${ }^{13}$

As emphasized, the strength of the banking system is positively related to bank liquidity, efficiency, and profitability. Regarding liquidity, we look at the ratio of bank liquid reserves to bank assets, where high ratios typically reflect strong banks. ${ }^{14}$ We also use information on bank deposits as a share of GDP, which - given the maturity mismatch - also

\footnotetext{
12 See www.worldbank.org/research/projects/finstructure/database.htm. The variables are compiled by using information from the IFS-IMF.

${ }^{13}$ This conclusion remains unchanged if we alternatively interpret the measures of (excessive) credit expansion as indicating the extent to which banks accommodate or propagate instable economic processes (like asset price bubbles).

${ }^{14}$ At the level of individual banks, excessive liquidity may indicate funding problems or other precautionary motives, thereby pointing to weakness rather than strength. At the level of a country's banking sector we do not expect liquidity to pick up this effect though.
} 
signals liquidity risks. Proxy variables of profitability are net interest rate margins and overhead costs. The net interest rate margin depicts the relative profitability of interestbearing assets and overhead costs represent the costs related to management and administration. While bank profitability and, accordingly, banking sector strength increases with net interest rate margins, it decreases with operating costs. Banking sector efficiency is approximated as the ratio of the interest rate margin over operating cost. The corresponding data are provided by the Worldbank. ${ }^{15}$

Besides these factors, the stability of the banking system also depends on the degree of foreign bank penetration, albeit in an uncertain way. In order to test the importance of foreign bank penetration as a determinant of bank stability and as a possible transmission channel of contagious shocks, we follow De Haas and Van Lelyveld (2004) and define this variable as follows. Using BIS reporting countries' data, the proxy variable is computed as the sum of cross-border claims in all currencies, local claims in non-local currencies, and local currency claims on local residents less cross-border claims with head offices outside the country. The result is divided by domestic credit as contained in the IFS. In order to conclude that foreign bank penetration stabilizes the domestic banking system, the resulting coefficient estimates should be negative, i.e. an increased presence of foreign banks in domestic credit provision should reduce the probability of a country being hit by contagion. ${ }^{16}$

\section{Empirical Results}

The probit model is estimated on a cross-sectional dataset that consists of 48 emerging and developing countries. ${ }^{17}$ This is a somewhat smaller number of countries than included in the dataset used by for example Van Rijckeghem and Weder (2001), who also include a number of developed European and North American countries. However, we feel that including nonemerging countries biases both the economic interpretation for emerging countries and the estimates (by raising the number of non-crisis observations relative to the number of crisis observations). The frequency of our data is annual, quarterly or monthly - depending on the specific variable - and covers the period 1993-1998.

Macroeconomic data are collected from the International Financial Statistics (IFS) publication of the International Monetary Fund (IMF). Our measure of trade competition is

\footnotetext{
15 The data are compiled from the World Development Indicators (CD-Rom 2004) and from www.worldbank.org/research/projects/finstructure/database.htm.

${ }_{16}$ Alternatively, foreign bank penetration would need to reduce the contagious impact of financial linkages. We show shortly that such interaction effects have little if any statistical significance in our analysis.

${ }^{17} \mathrm{~A}$ complete overview of the countries included in the sample is given in the appendix.
} 
built from annual data extracted from the IMF-International Trade Statistics. Competition for funds is computed from bi-yearly information on the consolidated banking activities by the Bank of International Settlements (BIS). To be more precise, the variable is constructed by considering aggregate bank loans from the BIS reporting countries to our sample countries. ${ }^{18}$ Missing data causes differences in the number of countries for which the measure of trade and financial linkages is available in each of the sampled crisis episodes. Finally, data on the strength of the banking sector are compiled from the IFS and from the records of the World Bank.

Equation (1) is estimated using the traditional maximum likelihood procedure for the Mexican, Asian, and Russian crises. We also report the z-statistics as well as the Mc-Fadden R-squared to judge the quality of the specification. In the first instance, we look at each variable separately to determine its role in the transmission of the crises in question (see the column headed 'univariate' in table 2). As in Van Rijckeghem and Weder (2001), the correlation matrix (table 1 ) reveals that the trade and funds competition, but also the various banking sector strength measures correlate quite strongly, which may lead to identification issues in the multivariate analysis. In addition to the univariate regressions, we assess for each variable in turn its explanatory power after controlling for trade and funds competition (see the column headed 'multivariate' in table 2). The comparison of these two experiments will indicate to what extent the bank sector strength measures augment the explanation of crisis transmission after controlling for what the literature by now considers the standard trade and finance channels. The results will be discussed more extensively below. Secondly, a multivariate analysis is performed. All the banking measures that have explanatory power, in addition to trade and funds competition, are included in a general model. Then, following the generalto-specific approach, all the variables not significant at a $20 \%$ error level are sequentially removed, leading to the parsimonious models reported in table 3 . The table additionally reports the model with trade and funds competition alone. In line with the literature in this field, we find that additional macroeconomic controls (real exchange rate changes, foreign exchange reserves, government budget and current account deficits and so on) have no additional explanatory power (e.g. Van Rijckeghem and Weder, 2001), limiting the support of a fundamentals-based view of the transmission of the crises. By contrast, in the case of the transmission of the Russian crisis, we find that our measures of banking sector strength do add explanatory power after controlling for trade and financial linkages. ${ }^{19}$

\footnotetext{
${ }^{18}$ The BIS reporting countries are Austria, Belgium, Canada, Denmark, Finland, France, Germany, Japan, Ireland, Italy, Luxemburg, Netherlands, Norway, Portugal, United Kingdom, United States, Spain, Sweden, Switzerland.

${ }_{19}$ The McFadden R-squared jumps from 0.09 to 0.30 when measures of banking sector strength are taken on board.
} 
From table 3 we also note that the explanatory power of our model (represented by the McFadden R-squared) is lower than that in Glick and Rose (1999) and Van Rijckeghem and Weder (2001). Such a result is inherent to the different sample we consider. As we exclude industrialized countries, the relative number of countries facing a currency cris is increases in our data set compared to the data sets used by Glick and Rose (1999) or Van Rijckeghem and Weder (2001), leading to a lower explanatory power. By focusing primarily on emerging economies, we face a more difficult task in separating those prone to contagion in any particular crisis. Yet at the same time we feel that any result will be far more powerful in understanding which countries, from a sample of countries that have demonstrated strong sensitivity to crisis contagion, are most at risk at any point in time. We now turn to a more detailed discussion of the results for each crisis separately.

\section{The Mexican crisis}

The Mexican crisis was spurred by a number of interacting factors related to regulatory deficiencies, credit growth, political uncertainty, and adverse external developments. In the course of the 1980s, Mexico experienced rapid economic growth that was induced by the liberalization of capital and trade flows. In the presence of a crawling pegged exchange rate system and low US interest rates, this development induced large capital inflows. At the same time, deregulation of the financial sector, a prosperous economic outlook, and a decline in public indebtedness triggered excessive credit growth. Given weak supervisory capacities by regulators, the absence of bank reserve requirements, the lack of expertise by undercapitalized financial institutions, and the consequent moral hazard problem, the lending boom deteriorates the quality of banks' loan portfolios. Furthermore, in stimulating capital investment and private consumption, the credit boom contributed to the emergence of an external deficit. This was largely financed by short-term USD denominated capital and became increasingly unsustainable given imprudent investment. The financial crisis erupted in December 1994.

Tables 2 (panel A) and 3 gather the results of our investigation concerning the transmission of the Mexican crisis. Firstly we observe that individually, measures of banking sector strength (deposits by banks, lending boom, and foreign bank penetration) have significant explanatory power. Due to their correlation with trade and funds competition, however, only foreign bank penetration augments the multivariate model. It turns out that the transmission of the Mexican crisis follows both trade and funds competition patterns. These results support a mixed view on the generation of the Mexican crisis. The trade channel supports a second-generation transmission of a currency crisis. Third generation models of currency crises also incorporate credit cycle models where the financial crisis 
originates with the asset side of banks' balance sheets (e.g. Breuer, 2004). This is in line with the observation that contaminated countries are more strongly in competition for funds with Mexico than the countries that remain unaffected by the contagious effects of the Mexican crisis. Hence, the crisis also tended to be transmitted via common lenders (cf. Van Rijckeghem and Weder, 2001; Sbracia and Zaghini, 2003). Additionally, some of our indicators of banking sector strength correlate with the crisis indicator, lending credence to the view that the transmission of the Mexican crisis was predominantly to countries that had recently experienced an overexpansion of bank credit (cf. Sachs et al., 1996; Tornell, 1999). Specifically, contaminated countries experienced a lending boom in the run-up to the tequila crisis and showed a larger share of bank assets to total financial assets. ${ }^{20}$ Interestingly, countries in which foreign banks had been more involved were also more likely to catch a tequila hangover, as indicated by the higher value of foreign bank penetration for the crisis countries. $^{21}$ This result may suggest that foreign banks provide instability to our samplecountries because they tend also to be the first ones to run when the going gets tough. However, foreign bank penetration may also reflect implicit or explicit guarantees on deposits provided by the host country. International banks have larger incentives to branch out to those host countries that provide some form of deposit insurance guarantees, rather than to hosts that do not. Deposit insurance guarantees create moral hazard on the part of the decisions of both local and international banks and may make the system as a whole vulnerable to shocks (cf. Sbracia and Zaghini, 2003). Alternatively, foreign bank penetration may reflect a high degree of financial openness and, as Kaminsky et al. (2003) point out, markets that are easily accessible and liquid are very sensitive to capital flight when hit by shocks. In addition to the variables reported in the table, we correlate a number of the more traditional macroeconomic control variables with the crisis index, such as GDP growth, the trade deficit, the budget deficit, interest rates, foreign exchange reserves, and the real exchange rate. None of these variables by themselves explain the transmission of the Mexican crisis.

\section{The Asian crisis}

A multitude of interdependent domestic and external factors are at the origin of the Asian crisis. The main cause of the East Asian crisis was a moral hazard problem at the corporate,

\footnotetext{
${ }^{20}$ In itself, a lending boom may point to a first-generation crisis, indicating an overall excessive growth in domestic credit. Our broader results suggest that it is the share of bank lending in total lending that drives our result. Moreover, unreported results show no signs of crisis countries running excessive budget deficits, the required closing piece of the first-generation view on currency crises.

${ }^{21}$ Interaction effects - defined as the product of foreign bank penetration and funds competition turn out insignificant. Hence we cannot conclude that the Mexican crisis spreads to countries with a strong presence of foreign banks that also have large exposures in Mexico.
} 
financial, and international level during the process of financial market liberalization in the 1990s. Corsetti et al. (1998) attribute the moral hazard problem to structural and policy distortions in the corporate and financial sectors. Distortions at the corporate level arose from public guarantees to favored private sectors and from bailout policies that created an environment of certainty regarding the return on risky and financially unsound investment projects.

Despite the low profitability of investment, investment rates in Asia were high. High investment was financed with credits from domestic financial institutions that borrowed heavily from abroad. The implications of these developments were twofold. Firstly, in lacking sound supervision, strong regulation, and transparency, the willingness of financial institutions to channel funds toward risky projects resulted in an undercapitalized financial system with a growing share of non-performing loans. Secondly, high investment rates stirred overheating pressures, inflated stock and real estate prices, and contributed to the emergence of current account deficits. The emergence of an external deficit was dangerous since the low profitability of the investment projects did not match the costs of borrowing funds from abroad.

The sustained high investment rates and subsequent overheating pressures were also fuelled by the maintenance of fixed exchange rate regimes. These offered implicit guarantees of exchange value and, through this effect, improved external access to especially short-term foreign-currency denominated funds. The consequent excessive exposure to foreign exchange risk increased the susceptibility of economies to extemal shocks. Next to these effects, the operation of fixed exchange rate regimes magnified the fragility of the Asian economies to adverse terms of trade shocks and to the consequent loss in external competitiveness as of the second half of 1995. Because most Asian countries were open to and interdependent with each other, adverse foreign demand shocks and terms of trade shocks had a pronounced negative effect on the performance of Asian economies in the second half of the 1990s. The external and domestic shocks revealed the fragility of the Asian countries that ultimately induced the eruption of the crisis in Thailand and through trade and financial linkages the subsequent collapse of other countries.

Results of our estimations as gathered in tables 2 (panel B) and 3 support this analysis. Trade and funds competition both exhibit a statistically significant explanation of the transmission of the Asian crisis in the univariate as well as the multivariate models. Some of the measures of banking sector strength explain crisis transmission univariately, but also correlate strongly with trade and funds competition so that they fail to add explanatory power in the multivariate models. Similar to the transmission of the Mexican crisis, the Asian crisis also transmits to countries broadly in accordance with patterns of trade and funds 
competition (cf. Van Rijckeghem and Weder, 2001). In addition, there is ample evidence in panel $\mathrm{B}$ of table 2 to support the view that Bahtulism spread to countries where the banking sector tended to have over-expanded its credit to the private sector, while at the same time seeming to have been more vulnerable to changes in the exchange rate. In particular, the table shows that bank assets relative to GDP was some fifteen percentage points higher in the crisis countries in comparison with the non-crisis countries. A similar result is obtained for private credit provision by banks. Sensitivity to exchange rate changes follows from the considerably higher foreign assets price risk for crisis countries, reflecting that the banking sectors in these countries were heavy net borrowers in foreign currency prior to the Asian crisis. Strikingly, the banking sectors in crisis countries also appear more efficient than their counterparts in non-crisis countries, as follows from the comparison of overhead costs. As Bongini et al. (2001) suggest, however, this may also reflect prior forbearance from prudential regulations by supervisors at the onset of the Asian crisis and contribute to the view of the crisis transmitting to countries with over exposed banking sectors. In line with a camouflaged weakness of the banking sector, we find that of the miscellaneous macroeconomic controls, the short-term interest rate tended to be lower in crisis countries prior to the collapse of the Thai Baht. This feature quickly disappeared when markets brought down the Thai currency.

\section{The Russian crisis}

The Russian crisis started on August 18, 1998 after the collapse of the Russian Ruble. Several studies have attempted to understand this event. Among them, Sutela (2000) stresses the large amount of government securities before the crisis, leading to a fragile situation in financial markets. The role of the Russian banking system in the collapse of the Russian Ruble is non negligible as the banks were important buyers of ruble denominated government securities. ${ }^{22}$

The situation of the Russian banking sector is thus quite weak before and after the 1998 crisis. In addition, with the Russian crisis erupting hardly more than a year after the Asian crisis, it may find many countries more sensitive to contagious effects than they were on the eve of the previous two crises. This may account for the fact that the Russian crisis tends to spread more across different regions (see table $A 1$ in the appendix). It turns out that - as in the Mexican and Asian crises - the Russian crisis spreads via the trade channel (see the univariate results in panel $C$ of table 2). Nevertheless, in contrast to the Mexican and Asian crisis, the funds competition channel does not appear to play a significant role. As

\footnotetext{
${ }^{22}$ In 1997, 30\% of banks' revenues was earned on these securities.
} 
before, we do find that patterns of banking sector strength can explain which countries suffered from the Russian crises, but the channel appears slightly different from both crises discussed before. Specifically, the Russian crisis did not spread, as did the Mexican crisis, to those countries that exhibited a boom in bank lending. Similarly, the crisis did not spread to countries whose banking sectors are overexposed to currency realignments, as tended to be the case in the Asian crisis. Rather, the Russian crisis infected those countries where the banking sectors exhibited inefficiencies, as indicated by higher overhead costs. Contrary to the Mexican and Asian crises, overhead costs now have significant explanatory power in the univariate as well as the multivariate models. The risks attached to inefficiencies in the banking sectors are also reflected in higher short-term interest rates in the crisis countries many months in advance of the crisis, demonstrating that in this instance at least, markets were not caught unawares. Of course, DeYoung and Whalen (1994), at the level of individual banks, show that weak banks may display operating inefficiencies as far as six years prior to actual failure. In that regard, inefficiencies at the level of the banking sector may be identified by financial markets well in advance of a crisis. The international risk premia applying to countries that would subsequently suffer the contagious effects of the Russian crisis are also reflected by the fact that the banking sectors in these countries tended to have on average higher interest rate margins than their counterparts in non-crisis countries.

Our results for the transmission of the Russian crisis underscores the main argument of this paper, namely that the strength of a country's banking sector provides an understanding of the vulnerability of this country to suffer from the contagious effects of currency crises abroad. Moreover, it does so after controlling for trade and financial linkages, which the economic literature on the topic by now regards as the standard channels through which currency crises spread from one country to another. ${ }^{23}$

\section{Conclusion}

This paper demonstrates that banking sector strength can help explain the transmission of the Mexican, Thai, and Russian crises. The various aspects, that jointly comprise banking sector strength, make it a factor that is hard to capture by a single variable, so that we include a number of macro-economic measures that are theoretically connected to banking sector strength. Given the many aspects of banking sector strength, the results are not surprising in the sense that they show that its role in the transmission of crises changes over

\footnotetext{
${ }^{23}$ Possibly we benefit from the fact that the Russian crisis spread more across regions, which allows for a richer specification of the transmission process than along the lines of such predominantly regional patterns such as trade and funds competition (cf. Van Rijckeghem and Weder, 2001).
} 
time. Specifically, the Mexican crisis spreads to countries with fast growth of domestic credit and with a stronger presence of foreign banks in the provision of domestic credits. The Thai crisis is also transmitted to those countries whose banking credits grew rapidly, but additionally to those countries that also exhibited stronger exposure to currency realignments. The Russian crisis, by contrast, spread predominantly to countries that displayed inefficiencies in their banking sectors in the form of higher overhead costs.

We also find that our measures of banking sector strength are highly correlated with trade and financial linkages, especially so in Asia where an independent role of banking sector strength is hard to detect once trade and financial linkages are controlled for. The transmission of the Russian crisis is a notable exception as in this case banking sector strength explains the transmission of the crisis even after controlling for trade and financial linkages. The Russian crisis also seems to have diffused relatively more across regions, yielding a higher degree of diversity of crisis countries and allowing for a richer analysis of crisis transmission.

The role of the banking sector in the transmission of crises deserves closer attention especially because our measurement of banking sector strength at the macro-economic level cannot be precise. Analysis of micro-data, specifically on (the distribution of) nonperforming loans in the banking sector, should yield considerably more precise measures of banking sector strength. However, micro-data on banks in developing countries only start to become available around the time of the Russian crisis. In that regard, our preliminary results on the independent role of the banking sector in crisis transmission in the Russian case are particularly encouraging for further research. 


\section{Table 1 Correlation Coefficients}

Panel A Mexican crisis (December 20, 1994)

\begin{tabular}{|c|c|c|c|c|c|c|c|c|c|c|c|c|c|c|}
\hline & $(1)$ & $(2)$ & (3) & (4) & (5) & (6) & (7) & (8) & (9) & (10) & (11) & $(12)$ & (13) & (14) \\
\hline (1) & 1.00 & & & & & & & & & & & & & \\
\hline (2) & 0.67 & 1.00 & & & & & & & & & & & & \\
\hline (3) & -0.09 & 0.12 & 1.00 & & & & & & & & & & & \\
\hline (4) & -0.25 & 0.06 & 0.77 & 1.00 & & & & & & & & & & \\
\hline (5) & -0.13 & 0.22 & 0.67 & 0.83 & 1.00 & & & & & & & & & \\
\hline (6) & -0.10 & 0.01 & 0.49 & 0.72 & 0.73 & 1.00 & & & & & & & & \\
\hline (7) & 0.17 & 0.16 & -0.28 & -0.58 & -0.52 & -0.42 & 1.00 & & & & & & & \\
\hline (8) & -0.06 & 0.03 & -0.23 & -0.46 & -0.44 & -0.33 & 0.75 & 1.00 & & & & & & \\
\hline (9) & 0.02 & 0.06 & 0.39 & 0.70 & 0.71 & 0.82 & -0.53 & -0.40 & 1.00 & & & & & \\
\hline (10) & 0.01 & -0.08 & 0.09 & -0.06 & -0.22 & -0.33 & 0.28 & 0.41 & -0.11 & 1.00 & & & & \\
\hline (11) & 0.05 & -0.17 & -0.38 & -0.38 & -0.37 & -0.21 & 0.23 & 0.12 & -0.13 & 0.07 & 1.00 & & & \\
\hline (12) & -0.02 & 0.09 & 0.08 & 0.19 & -0.10 & 0.08 & -0.19 & 0.15 & 0.38 & -0.09 & 0.04 & 1.00 & & \\
\hline (13) & 0.01 & 0.00 & 0.33 & 0.43 & -0.01 & 0.23 & -0.15 & -0.28 & 0.33 & -0.06 & -0.17 & 0.25 & 1.00 & \\
\hline (14) & 0.27 & 0.34 & -0.14 & 0.02 & 0.13 & 0.03 & 0.19 & -0.16 & -0.12 & -0.27 & -0.08 & 0.10 & 0.16 & 1.00 \\
\hline
\end{tabular}

\section{Panel B Asian crisis (J uly 2, 1997)}

\begin{tabular}{|c|c|c|c|c|c|c|c|c|c|c|c|c|c|c|}
\hline & (1) & (2) & (3) & (4) & (5) & (6) & (7) & (8) & (9) & (10) & (11) & (12) & (13) & (14) \\
\hline (1) & 1.00 & & & & & & & & & & & & & \\
\hline (2) & 0.56 & 1.00 & & & & & & & & & & & & \\
\hline (3) & 0.10 & 0.32 & 1.00 & & & & & & & & & & & \\
\hline (4) & 0.22 & 0.37 & 0.82 & 1.00 & & & & & & & & & & \\
\hline (5) & 0.30 & 0.43 & 0.78 & 0.93 & 1.00 & & & & & & & & & \\
\hline (6) & 0.12 & 0.22 & 0.60 & 0.79 & 0.77 & 1.00 & & & & & & & & \\
\hline (7) & -0.30 & -0.34 & -0.58 & -0.69 & -0.69 & -0.46 & 1.00 & & & & & & & \\
\hline (8) & -0.13 & -0.19 & -0.48 & -0.60 & -0.53 & -0.40 & 0.85 & 1.00 & & & & & & \\
\hline (9) & 0.45 & 0.54 & 0.48 & 0.75 & 0.81 & 0.79 & -0.63 & -0.55 & 1.00 & & & & & \\
\hline $\begin{array}{l}(10) \\
\text { (11) }\end{array}$ & $\begin{array}{l}-0.12 \\
-0.11\end{array}$ & $\begin{array}{l}-0.19 \\
-0.27\end{array}$ & $\begin{array}{l}-0.11 \\
-0.32\end{array}$ & $\begin{array}{l}-0.19 \\
-0.34\end{array}$ & $\begin{array}{l}-0.20 \\
-0.36\end{array}$ & $\begin{array}{l}-0.19 \\
-0.21\end{array}$ & $\begin{array}{l}0.09 \\
0.19\end{array}$ & $\begin{array}{l}0.12 \\
0.14\end{array}$ & $\begin{array}{l}-0.19 \\
-0.19\end{array}$ & $\begin{array}{r}1.00 \\
-0.14\end{array}$ & 1.00 & & & \\
\hline (12) & 0.18 & 0.19 & 0.30 & 0.54 & 0.57 & 0.87 & -0.18 & -0.14 & 0.69 & -0.21 & -0.17 & 1.00 & & \\
\hline (13) & 0.29 & 0.29 & 0.14 & 0.23 & 0.29 & 0.10 & -0.29 & -0.15 & 0.31 & 0.11 & 0.01 & 0.04 & 1.00 & \\
\hline (14) & 0.17 & 0.29 & -0.05 & 0.03 & 0.17 & 0.04 & -0.09 & -0.01 & 0.27 & -0.24 & -0.11 & 0.18 & 0.40 & 1.00 \\
\hline
\end{tabular}

\section{Panel C Russian crisis (August 18, 1998)}

\begin{tabular}{|c|c|c|c|c|c|c|c|c|c|c|c|c|c|c|}
\hline & (1) & (2) & (3) & (4) & (5) & (6) & (7) & (8) & (9) & (10) & (11) & (12) & (13) & (14) \\
\hline (1) & 1.00 & & & & & & & & & & & & & \\
\hline (2) & 0.22 & 1.00 & & & & & & & & & & & & \\
\hline (3) & -0.49 & 0.23 & 1.00 & & & & & & & & & & & \\
\hline (4) & -0.37 & 0.28 & 0.83 & 1.00 & & & & & & & & & & \\
\hline (5) & -0.41 & 0.34 & 0.83 & 0.95 & 1.00 & & & & & & & & & \\
\hline (6) & -0.40 & 0.09 & 0.68 & 0.85 & 0.82 & 1.00 & & & & & & & & \\
\hline (7) & 0.32 & -0.20 & -0.60 & -0.61 & -0.61 & -0.40 & 1.00 & & & & & & & \\
\hline (8) & 0.26 & -0.02 & -0.52 & -0.60 & -0.56 & -0.49 & 0.79 & 1.00 & & & & & & \\
\hline (9) & -0.24 & 0.39 & 0.57 & 0.79 & 0.84 & 0.81 & -0.55 & -0.48 & 1.00 & & & & & \\
\hline (10) & 0.35 & 0.10 & -0.14 & -0.27 & -0.28 & -0.28 & -0.02 & 0.13 & -0.26 & 1.00 & & & & \\
\hline (11) & 0.04 & -0.34 & -0.30 & -0.31 & -0.32 & -0.17 & 0.22 & 0.20 & -0.08 & 0.01 & 1.00 & & & \\
\hline (12) & -0.18 & 0.13 & 0.32 & 0.56 & 0.57 & 0.78 & 0.01 & -0.14 & 0.66 & -0.26 & -0.20 & 1.00 & & \\
\hline (13) & -0.06 & 0.16 & 0.18 & 0.12 & 0.15 & 0.06 & -0.35 & -0.14 & 0.16 & 0.11 & 0.06 & -0.03 & 1.00 & \\
\hline (14) & 0.00 & 0.15 & 0.11 & 0.09 & 0.17 & 0.12 & -0.34 & -0.10 & 0.33 & -0.01 & -0.03 & 0.05 & 0.40 & 1.00 \\
\hline
\end{tabular}

Note, Funds Competition (1), Trade Competition (2), Domestic credit provided by banks (3), Bank assets to GDP (4), Private credit by banks (5), Deposits by banks (6), Overhead costs (7), Net interest margin (8), Claims on the private sector (9), Claims on the government (10), Bank liquid reserves to assets (11), Foreign bank penetration (12), Foreign assets price risk (13), Lending boom (14). 
Table 2 Descriptive statistics per crisis

\begin{tabular}{|c|c|c|c|c|c|}
\hline & \multirow[t]{2}{*}{ \# Obs. } & \multicolumn{2}{|c|}{ Country mean values } & \multicolumn{2}{|c|}{ Z-statistic in probit model ${ }^{1}$} \\
\hline & & Crisis & Non-crisis & Univariate & Multivariate $^{2}$ \\
\hline \multicolumn{6}{|c|}{ Panel A Mexican crisis ( December 20, 1994) } \\
\hline Funds competition & 48 & 0.67 & 0.47 & $2.22^{* * *}$ & - \\
\hline Trade competition & 47 & 0.04 & 0.02 & $3.09^{* * *}$ & - \\
\hline Bank assets to GDP & 42 & 0.50 & 0.44 & 0.45 & 0.39 \\
\hline Private credit by banks & 42 & 0.45 & 0.32 & 1.16 & 0.77 \\
\hline Deposits by banks & 44 & 0.64 & 0.36 & $1.34^{*}$ & $1.37^{*}$ \\
\hline Overhead costs & 41 & 0.06 & 0.04 & 1.21 & 0.69 \\
\hline Net interest margin & 37 & 0.07 & 0.06 & 0.55 & 0.40 \\
\hline Claims on the private sector & 22 & 0.48 & 0.35 & 0.84 & 1.03 \\
\hline Claims on the government & 22 & 0.05 & 0.11 & -1.00 & -1.20 \\
\hline Domestic credit provided by banks & 47 & 0.74 & 0.62 & 0.71 & 0.56 \\
\hline Bank liquid reserves to assets & 46 & 0.12 & 0.16 & -1.01 & -0.70 \\
\hline Lending boom & 33 & 0.89 & 0.22 & $2.16^{* * *}$ & $1.53^{*}$ \\
\hline Foreign bank penetration & 47 & 0.04 & 0.01 & $1.79^{* *}$ & $1.66^{* *}$ \\
\hline Foreign assets price risk & 41 & 0.31 & 0.23 & 0.00 & -0.04 \\
\hline \multicolumn{6}{|l|}{ Panel B Asian crisis (J uly 2, 1997) } \\
\hline Funds competition & 48 & 0.57 & 0.41 & $2.78^{* * *}$ & - \\
\hline Trade competition & 47 & 0.15 & 0.04 & $3.05^{* * *}$ & - \\
\hline Bank assets to GDP & 47 & 0.54 & 0.39 & $1.68^{* *}$ & 0.61 \\
\hline Private credit by banks & 46 & 0.46 & 0.31 & $1.80^{* *}$ & 0.45 \\
\hline Deposits by banks & 47 & 0.38 & 0.36 & 0.24 & 0.04 \\
\hline Overhead costs & 47 & 0.04 & 0.05 & $-1.70^{* *}$ & -0.42 \\
\hline Net interest margin & 45 & 0.05 & 0.06 & $-1.32^{*}$ & -0.81 \\
\hline Claims on the private sector & 27 & 0.36 & 0.21 & 0.68 & -0.53 \\
\hline Claims on the government & 27 & 0.10 & 0.06 & 0.66 & 0.66 \\
\hline Domestic credit provided by banks & 47 & 0.69 & 0.54 & 0.92 & 0.22 \\
\hline Bank liquid reserves to assets & 46 & 0.11 & 0.14 & -0.79 & -0.20 \\
\hline Lending boom & 42 & 0.54 & 0.37 & 0.86 & -0.42 \\
\hline Foreign bank penetration & 48 & 0.02 & 0.01 & $1.48^{*}$ & 0.96 \\
\hline Foreign assets price risk & 47 & 0.06 & -0.11 & $1.98^{* * *}$ & 0.61 \\
\hline \multicolumn{6}{|c|}{ Panel C Russian crisis (August 18, 1998) } \\
\hline Funds competition & 48 & 0.57 & 0.56 & -0.32 & - \\
\hline Trade competition & 47 & 0.05 & 0.03 & $2.21^{* * *}$ & - \\
\hline Bank assets to GDP & 47 & 0.50 & 0.48 & 0.15 & -1.06 \\
\hline Private credit by banks & 47 & 0.45 & 0.39 & 0.57 & -0.79 \\
\hline Deposits by banks & 47 & 0.47 & 0.40 & 0.65 & 0.10 \\
\hline Overhead costs & 48 & 0.05 & 0.04 & $1.45^{*}$ & $2.42^{* * *}$ \\
\hline Net interest margin & 46 & 0.07 & 0.05 & $1.38^{*}$ & $1.79^{* *}$ \\
\hline Claims on the private sector & 28 & 0.46 & 0.41 & 0.28 & -0.72 \\
\hline Claims on the government & 28 & 0.03 & 0.09 & $-1.39^{*}$ & $-1.51^{*}$ \\
\hline Domestic credit provided by banks & 47 & 0.61 & 0.66 & -0.33 & $-1.56^{*}$ \\
\hline Bank liquid reserves to assets & 46 & 0.09 & 0.12 & -1.07 & -0.35 \\
\hline Lending boom & 43 & 0.36 & 0.53 & -0.98 & $-1.39^{*}$ \\
\hline Foreign bank penetration & 48 & 0.09 & 0.01 & 0.55 & 0.64 \\
\hline Foreign assets price risk & 45 & -0.00 & -0.05 & 0.44 & -0.02 \\
\hline
\end{tabular}

Notes: Lending boom is defined as the four-year percentage change in the ratio of the size of the claims on the banking sector (demand deposit banks and monetary authorities) on the private sector to GDP (cf. Sachs et al., 1996).

${ }^{1}$ Significance at the 20,10 , and 5 percent error level is indicated by ${ }^{*},{ }^{* *}$ and ${ }^{* * *}$, respectively.

2 The multivariate results evaluate the additional explanatory power of the respective variable in a model that already incorporates trade and funds competition. 
Table 3 Multivariate analysis

\begin{tabular}{|c|c|c|c|c|c|}
\hline Variable & $\begin{array}{r}\text { Mexic } \\
\text { (Decemb }\end{array}$ & $\begin{array}{l}\text { Crisis } \\
20,1994)\end{array}$ & $\begin{array}{c}\text { Asian Crisis } \\
\text { (J uly 2, 1997) }\end{array}$ & $\begin{array}{l}\text { Russ } \\
\text { (Augus }\end{array}$ & $\begin{array}{l}\text { Crisis } \\
8,1998)\end{array}$ \\
\hline Constant & $\begin{array}{c}-2.140 * * * \\
(-2.835)\end{array}$ & $\begin{array}{c}-2.770^{*} * \bar{*} \\
(-2920)\end{array}$ & $\begin{array}{c}-2.432 * * * \\
(-2742)\end{array}$ & $\begin{array}{c}-0.286 \\
-0375)\end{array}$ & -1.020 \\
\hline Funds competition & $\begin{array}{c}0.005 \\
(0.316)\end{array}$ & $\begin{array}{c}0.012 \\
(0.611)\end{array}$ & $\begin{array}{c}0.024^{*} \\
(1.317)\end{array}$ & $\begin{array}{c}-0.012 \\
(-0.891)\end{array}$ & $\begin{array}{c}-0.030 * * \\
(-1.829)\end{array}$ \\
\hline Trade competition & $\begin{array}{c}0.446 * * * \\
(2.069)\end{array}$ & $\begin{array}{l}0.361 * * \\
(1.671)\end{array}$ & $\begin{array}{c}0.102 * * * \\
(2.587)\end{array}$ & $\begin{array}{c}0.155^{* * *} * \\
(2.340)\end{array}$ & $\begin{array}{c}0.284^{* * *} \\
(3.115)\end{array}$ \\
\hline Foreign bank penetration & & $\begin{array}{l}0.119 * * \\
(1.660)\end{array}$ & & & \\
\hline Overhead costs & & & & & $\begin{array}{c}0.142 \\
(1.177)\end{array}$ \\
\hline Short-term interest rate & & & & & $\begin{array}{l}0.032 * \\
(1.549) \\
\end{array}$ \\
\hline McFadden R-squared & 0.240 & 0.329 & 0.332 & 0.094 & 0.302 \\
\hline Observations & 47 & 46 & 46 & 47 & 44 \\
\hline LR Statistic & $11.040 * * *$ & $13.975 * * *$ & $18.164 * * *$ & $5.867 * *$ & $17.997 * * *$ \\
\hline
\end{tabular}

Notes: Probit estimates of our binary crisis variables (as defined by Glick and Rose, 1999 and Van Rijckeghem and Weder, 2001) with Z-statistics in parentheses. Significance at the 20,10 , and 5 percent error level is indicated by ${ }^{*},{ }^{* *}$ and ${ }^{* * *}$, respectively. 


\section{References}

- Bongini, P., S. Claessens, and G. Ferri (2001). The Political Economy of Distress in East Asian Financial Institutions. J ournal of Financial Services Research, Vol. 19 (1), pp. 5-25.

- Breuer, J.B. (2004). An Exegesis on Currency and Banking Crises. Journal of Economic Surveys, Vol. 18 (3), pp. 293-320.

- Candelon. B, A. Hecq, and W. Verschoor (2005). Measuring Common Cyclical Features During Financial Turmoil: Evidence of Interdependence not Contagion. Forthcoming Journal of International Money and Finance.

- Caramazza, F., L.A. Ricci, and R. Salgado (2000). Trade and Financial Contagion in Currency Crises. Washington DC: IMF Working Paper No. 00/55.

- Corsetti, G., P. Pesenti, and N. Roubini (1998). What caused the Asian Currency and Financial Crisis? Part I: A Macroeconomic Overview. Cambridge (Mass.): NBER Working Paper No. 6833.

- Demirgüç-Kunt, A. and E. Detragiache (1998). The Determinants of Banking Crises in Developing and Developed Countries, I MF Staff Papers, Vol. 45(1), pp. 81-109.

- DeYoung, R. and G. Whalen (1994). Banking Industry Consolidation: Efficiency Issues. Jerome Levy Economics Institute: Working Paper No. 110.

- Eichengreen, B., A.K. Rose, and C. Wyplosz (1996). Contagious Currency Crises. Scandinavian J ournal of Economics, Vol.98 (4), pp. 463-484.

- Forbes, K.J . and R. Rigobon (2002). No Contagion, only Interdependence: Measuring Stock Market Co-Movements. J ournal of Finance, Vol. 57 (5), pp. 2223-2261.

- Fries, S., D. Neven, and P. Seabright (2002). Bank Performance in Transition Economies. William Davidson Institute Working Paper No. 505.

- Glick, R. and A.K. Rose (1999). Contagion and Trade: Why are Currency Crises Regional? J ournal of International Money and Finance, Vol. 18(4), pp. 603-617.

- Haas, R.T.A. de, and I.P.P. van Lelyveld (2004). Foreign Bank Penetration and Private Sector Credit in Central and Eastern Europe. Journal of Emerging Markets Finance, Vol. 3(2), pp. 125-151.

- Haas, R.T.A. de, and I.P.P. van Lelyveld (2005), Foreign Banks and Credit Stability in Central and Eastern Europe: A Panel Data Analysis, Journal of Banking and Finance, forthcoming.

- Hardy, D.C, and C. Pazarbasioglu (1998). Determinants and Leading Indicators of Banking Crises: Further Evidence, IMF Staff Papers, 46(3), pp. 247-258.

- Herrero, A.G. (1999). Bank Specific Macroeconomic Indicators of the Venezuelan Banking Crisis: An Event History Analysis, European Central Bank, Mimeo.

- Kaminsky, G.L. (1998). Currency and Banking Crises: The Early Warnings of Distress. FRB International Finance Dis cussion Paper No. 629. 
- Kaminsky, G.L. and C.M. Reinhart (1999). The Twin Crises: The Causes of Banking and Balance-of-Payments Problems. American Economic Review, Vol. 89(3), pp. 473-500.

- Kaminsky, G.L. and C.M. Reinhart (2000). On Crises, Contagion, and Confusion. Journal of International Economics, Vol. 51(1), pp. 145-168.

- Kaminsky, G.L., C.M. Reinhart and C.A. Vegh (2003). The Unholy Trinity of Financial Contagion, Journal of Economic Perspectives, Vol. 17(4), pp. 51-74.

- Krugman, P. (1999). Balance Sheets, the Transfer Problem, and Financial Crises. International Tax and Public Finance, Vol. 6(4), pp. 459-472.

- Lindgren, C.-J., G.G.H. Garcia and M.I. Saal (1996). Bank Soundness and Macroeconomic Policy. Washington DC: International Monetary Fund.

- Morgan, D., B. Rime and P.E. Strahan (2003), Bank Integration and State Business Volatility, Cambridge (Mass.): NBER Working Paper No. 9704.

- Peek, J. and E.S. Rosengreen (2000). Implications of the Globalization of the Banking Sector: The Latin American Experience. New England Economic Review, pp. 45-62.

- Rijckeghem, C. van, and B.S. Weder (2001). Sources of Contagion: Is it Finance or Trade? J ournal of International Economics, Vol. 54(2), pp. 293-308.

- Sachs, J., A. Tornell and A. Velasco (1996). Financial Crises in Emerging Markets: The Lessons from 1995. Brooking Papers on Economic Activity No.1, pp. 147-215.

- Saxena, S.C. (2004). The Changing Nature of Currency Crisis. Journal of Economic Surveys, Vol. 18 (3), pp. 321-350.

- Sbracia, M. and A. Zaghini (2003). The Role of the Banking System in the International Transmission of Shocks. World Economy, Vol. 26 (5), pp. 727-754.

- Sutela, P. (2000). The Financial Crisis in Russia. In Global Financial Crises: Lessons from Recent events, Eds. J.R Bisignano, W.C. Hunter, G.G.Kaufman, BIS and FED of Chicago.

- Tornell, A. (1999). Common Fundamentals in the Tequila and Asian Crises. Cambridge (Mass.): NBER Working Paper No. 7139. 


\section{Appendix. Variable Description}

Crisis Indicator

Table A1 Crisis ( 1 ) and non-crisis ( 0 ) countries

\section{Mexican crisis Asian crisis Russian crisis}

\begin{tabular}{|c|c|c|}
\hline Argentina & 1 & 1 \\
\hline Bolivia & 0 & 0 \\
\hline Brazil & 1 & 1 \\
\hline Chile & 0 & 0 \\
\hline Colombia & 0 & 0 \\
\hline Costa Rica & 0 & 0 \\
\hline Czech Republic & 0 & 1 \\
\hline Ecuador & 0 & 0 \\
\hline Egypt & 0 & 0 \\
\hline Ghana & 0 & 0 \\
\hline Greece & 0 & 0 \\
\hline Hong Kong & 1 & - \\
\hline Hungary & 1 & 1 \\
\hline India & 0 & 0 \\
\hline Indonesia & 1 & 1 \\
\hline Israel & 0 & 0 \\
\hline Jordan & 0 & 0 \\
\hline Kenya & 0 & 0 \\
\hline Korea & 0 & 1 \\
\hline Latvia & 0 & 0 \\
\hline Lithuania & 0 & 0 \\
\hline Malaysia & 0 & 1 \\
\hline Mauritius & 0 & 0 \\
\hline Mexico & - & 1 \\
\hline Morocco & 0 & 0 \\
\hline Nigeria & 0 & 0 \\
\hline Pakistan & 0 & 1 \\
\hline Panama & 0 & 0 \\
\hline Peru & 1 & 0 \\
\hline Philippines & 1 & 1 \\
\hline Poland & 0 & 1 \\
\hline Portugal & 0 & 0 \\
\hline Russia & 0 & 0 \\
\hline Singapore & 0 & 1 \\
\hline South Africa & 0 & 1 \\
\hline Sri Lanka & 0 & 0 \\
\hline Thailand & 1 & - \\
\hline Turkey & 0 & 0 \\
\hline Ukraine & 0 & 0 \\
\hline Uruguay & 0 & 0 \\
\hline Venezuela & 1 & 0 \\
\hline Zimbabwe & 0 & 0 \\
\hline Japan & 0 & 0 \\
\hline Romania & 0 & 0 \\
\hline Slovakia & 0 & 0 \\
\hline Bulgaria & 0 & 0 \\
\hline Estonia & 0 & 0 \\
\hline Slovenia & 0 & 0 \\
\hline
\end{tabular}

Source: Glick and Rose (1999) and Van Rijckeghem and Weder (2001). Glick and Rose rely on The Financial Times reports mainly to identify the victims of the transmission of the Mexican and Asian crisis. Van Rijckeghem and Weder construct an analogous crisis indicator based on the views of IMF economists to determine if a country suffered from contagion in the wake of the Russian crisis. 


\section{Trade Indicator}

The definition of the trade variable follows Glick and Rose (1999), who define trade competition as the share of exports to a common destination $\mathrm{k}$ according to

$$
\operatorname{TRD}_{\mathrm{i}}=\sum_{\mathrm{k}}\left\{\left[\frac{\left(\mathrm{x}_{0 \mathrm{k}}+\mathrm{x}_{\mathrm{ik}}\right)}{\left(\mathrm{x}_{0 .}+\mathrm{x}_{\mathrm{i} .}\right)}\right]\left[1-\frac{\left|\left(\mathrm{x}_{0 \mathrm{k}} / \mathrm{x}_{0 .}-\mathrm{x}_{\mathrm{ik}} / \mathrm{x}_{\mathrm{i} .}\right)\right|}{\left(\mathrm{x}_{0 \mathrm{k}} / \mathrm{x}_{0 .}+\mathrm{x}_{\mathrm{ik}} / \mathrm{x}_{\mathrm{i}}\right)}\right]\right\},
$$

where $k \neq i, 0$. The variables $x_{i}$ and $x_{0}$. denote aggregate exports from country $i$ and ground zero, respectively. $x_{i k}$ and $x_{0 k}$ represent exports from country $i$ and ground zero to country $k$. The first component on the right-hand-side depicts the importance of country $k$ as an export destination for country $\mathrm{i}$ and the ground zero country relative to aggregate exports of country $i$ and ground zero. The second term denotes the relative importance of country $k$ as anexporting destination of ground zero and country $i$ and, hence, the extent to which both countries compete to export to country k. A high value of this index points to a high degree of competition between ground zero and country $\mathrm{i}$ in third markets.

\section{Finance Indicator}

Following Van Rijckeghem and Weder (2001), the measure of competition for funds in third markets applies the measure of trade competition in shares (A3) to flows of international bank loans. In this application $x_{o k}$ and $x_{i k}$ now represent bank loans from country $k$ to ground zero and country 1 , respectively, while $x_{0}$. and $x_{i}$ denote total bank loans to ground zero and country i. A high value of the funds competition measure suggests strong competition between country $\mathrm{i}$ and the ground zero country for bank loans from the same third markets.

\section{Macroeconomic Indicators}

The internal and external balance can be approximated by a multitude of economic variables. ${ }^{24}$ We include the pre-crisis current account deficit, the pre-crisis ratio of domestic liquidity to international reserves, real GDP growth, the government budget deficit as a percentage of GDP, growth of credit to the private sector, the ratio of short-term debt to international reserves, and the short-term interest rate as measure of financial market pressure. Furthermore, we incorporate the pre-crisis rate of real appreciation. Ideally, the degree of exchange rate under-valuation should be measured using a trade-weighted index of real exchange rates (e.g. Van Rijckeghem and Weder, 2001). Because real effective

\footnotetext{
${ }^{24}$ Kaminsky and Reinhart (2000) include 18 financial and macroeconomic time series. Details are in Kaminsky and Reinhart (1999) and Kaminsky (1998).
} 
exchange rate data are only available for a small sample of countries, the present analysis approximates the under-valuation of the currency by means of the bilateral real exchange rate defined in terms of U.S. dollars. Since the bilateral and effective real exchange rate are strongly correlated for those countries for which both measures are available, the empirical results are not expected to depend on our alternative definition of the real exchange rate.

\section{Banking Indicator}

The following table summarizes the definition of the measures of banking sector strength and the corresponding data sources.

\section{Table A2 Defining banking sector strength}

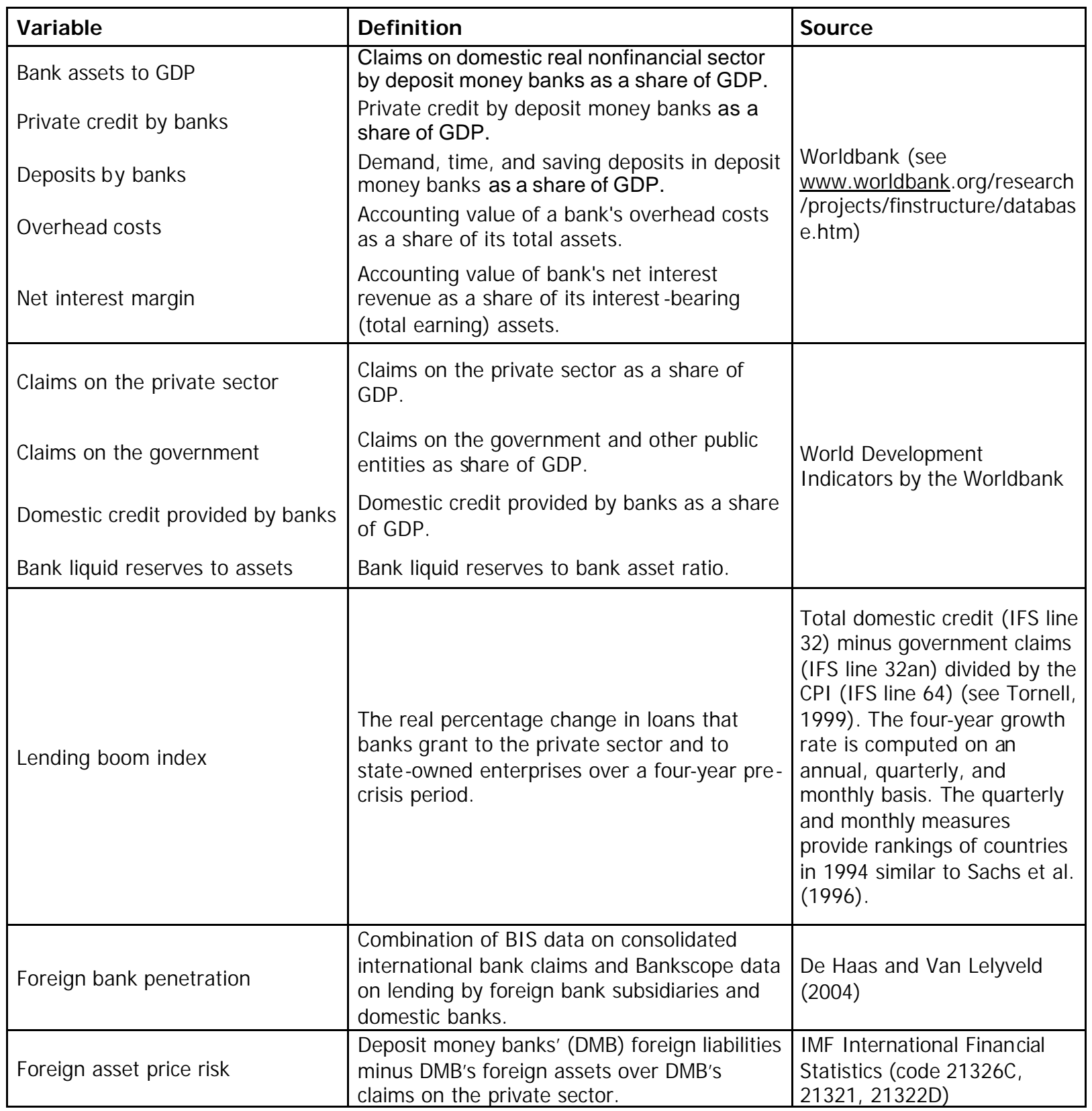

